\title{
Counterparty Credit Limit: Identifikasi, Pengukuran dan Pemetaan Risiko Bank-Bank di Indonesia
}

\author{
Saur Costanius Simamora \\ Program Studi Manajemen, Universitas Dirgantara Marsekal Suryadarma \\ Jl. Halim Perdana Kusuma, RT.1/RW.9, Kec. Makasar, Kota Jakarta Timur, Indonesia \\ saurcsimamora@gmail.com
}

Diterima: 09-02-2021

Disetujui: 16-06-2021

Dipublikasi: 30-06-2021

\begin{abstract}
ABSTRAK
Penelitian ini bertujuan untuk melakukan perencanaan manajemen risiko, identifikasi, analisis kualitatif dan perhitungan kuantitatif risiko penetapan counterparty credit limit pada bank-bank di Indonesia. Proses identifikasi risiko menggunakan metode pendapat ahli (expert opinion) dari 59 tenaga ahli bidang financial institution bankbank di Indonesia. Kemudian tahap analisis secara kualitatif menggunakan metode rating schemes dengan dua dimensi yaitu kemungkinan (probability) dan dampak (impact). Setiap risiko-risiko termasuk diukur untuk dimasukkan ke dalam kategori rendah (Low), sedang (Medium) dan tinggi (High). Hasil proses identifikasi ditemukan ada 18 risiko yang dihadapi oleh bank-bank di Indonesia. Hasil analisis kuantitatif dari risiko-risiko tersebut dengan dimensi Probability - Impact diketahui bahwa pada kuadran Low - Medium terdapat 1 risiko. Kemudian pada kuadran Medium - Medium terdapat 3 risiko. Pada kuadran Medium-High terdapat 8 risiko, sedangkah kuadran High - High terdapat 6 risiko. Hasil metode Delphi dari dimensi probabilitas menunjukkan risiko salah dalam menganalisa kinerja keuangan counterparty (analisa neraca, arus kas, laporan R/L, financial ratio) dan tidak memonitor dan memperhatikan sanksi-sanksi atau kasus hukum yang terjadi pada counterparty dengan nilai 2,29 dan para ahli (expert) telah tercapai konvergensi atau konsensus. Sedangkan dari dimensi dampak risiko salah dalam menganalisa kinerja keuangan counterparty (analisa neraca, laporan R/L, financial ratio) dengan nilai 2,78 dan para ahli (expert) telah tercapai konvergensi atau konsensus.
\end{abstract}

Kata Kunci:

Risiko Kredit; Pendapat Ahli; Rating; Limit Antar Bank; Metode Delphi

\begin{abstract}
This study aims to carry out risk management planning, identification, qualitative analysis and quantitative risk calculations, establishing counterparty credit limits on banks in Indonesia. The risk identification process utilize 59 expert views from the field of financial institution banks in Indonesia. Subsequently the qualitative analysis stage employ the two dimension rating schemes method, namely probability and impact. Each included risk is measured in the Low, Medium and High category. The identification process resulted in 18 risks that are facing banks in Indonesia. From that risks, the quantitative analysis using Probability - Impact dimension shows that in the Low - Medium quadrant there is 1 risk. In the Medium - Medium quadrant there are 3 risks. In the MediumHigh quadrant there are 8 risks. While the High - High quadrant resulted in 6 risks. The Delphi method output from the probability dimension, indicates the risk of error in analyzing the counterparty's financial performance (balance sheet analysis, cashflow, income statement, financial ratio) and not monitoring and recognizing sanctions or legal cases that occur to counterparties give a value of 2.29. While from the Impact dimension, the risk of error in analyzing the counterparty's financial performance (balance analysis, $R / L$ report, financial ratio) give a value of 2.78. All of these results, the experts have reached convergence or consensus.
\end{abstract}

Keywords:

Credit Risk; Expert Opinion; Rating Schemes; Counterparty Limits; Delphi Method 


\section{PENDAHULUAN}

Global Financial Crisis tahun 2008 mendorong peningkatan prinsip kehati-hatian dalam aktivitas over the counter (OTC) derivatives, penyempurnaan terhadap kerangka Counterparty Credit Risk (CCR) yang ada dalam peraturan di Indonesia perlu disempurnakan agar sesuai dengan kerangka Basel II dan Basel III sebagaimana diamanatkan oleh BCBS (Basel Committee on Banking Supervision) yang berlaku secara internasional. Beberapa penyempurnaan yang diterapkan dalam dokumen Basel II dan Basel III tersebut adalah Manajemen Risiko CCR, Perlakuan terhadap CCR pada Trading Book, Perhitungan Credit Valuation Adjustment (CVA), Wrong Way Risk, Collateralised Counterparties dan Margin Period of Risk serta mengatasi ketergantungan pada peringkat kredit eksternal dan meminimalkan Cliff Effect.

Indonesia yang merupakan salah satu negara anggota Basel Committee on Banking Supervision (BCBS) berkomitmen untuk menerapkan Basel Regulatory Framework sesuai dengan tenggat waktu (timeline) yang ditentukan, dimana salah satunya mencakup penyempurnaan kerangka counterparty credit risk. Hal ini tentunya dipertimbangkan dengan tetap mempertimbangkan dampaknya terhadap perbankan nasional.

Menurut Peraturan Otoritas Jasa Keuangan Nomor 18 /POJK.03/2016 definisi dari Counterparty Credit Risk (CCR) merupakan risiko yang timbul akibat terjadinya kegagalan pihak lawan dalam memenuhi kewajibannya dan timbul dari jenis transaksi yang memiliki karakteristik tertentu, misalnya transaksi yang dipengaruhi oleh pergerakan nilai wajar atau nilai pasar.

OJK (2015) Counterparty Credit Risk (CCR) merupakan bentuk risiko kredit, hal ini akan mencakup pemenuhan standar kerangka tersebut mengenai pendekatan untuk melakukan stress testing, "risiko residual" yang terkait dengan teknik mitigasi risiko kredit, dan konsentrasi kredit. bank harus memiliki kebijakan, proses dan sistem manajemen CCR yang secara konseptual baik dan diimplementasikan dengan integritas relatif terhadap kecanggihan dan kompleksitas dari kepemilikan suatu perusahaan terhadap eksposur yang menimbulkan CCR. Sebuah kerangka kerja manajemen CCR yang baik meliputi identifikasi, pengukuran, manajemen, persetujuan dan pelaporan internal CCR.

Penelitian mengenai risiko dalam penetapan Counterparty credit limit telah banyak dilakukan oleh lembaga riset dan akademisi. Emmawati dan Jogiyanto (2013), mengatakan bahwa Credit Line (CL) adalah batasan maksimal kredit yang diberikan kepada Bank Koresponden dalam bertransaksi Money Market (MM), Valuta Asing (Forex), dan Transaksi Komersial (perdagangan). Alokasi Credit Line bersifat tidak diinformasikan berapa nilainya (unadvised) dan tidak terikat (uncomitted) kepada bank koresponden berdasarkan penilaian risiko kredit bank koresponden.

Penelitian ini bertujuan untuk mengidentifikasi risiko-risiko apa saja yang mungkin dan akan terjadi dalam proses penetapan counterparty credit limit, lalu bagaimana hasil analisis kualitatif dan kuantitatif risiko-risiko tersebut berdasarkan pendapat ahli (expert opinion). Kemudian risiko apa yang paling penting untuk mendapatkan skala prioritas berdasarkan dimensi probabilitas (probability) dan dampak (impact). 
Manajemen risiko yang akan dilakukan mengacu kepada teori manajemen risiko dari Pritchard. Tahapan manajemen risiko yang dijabarkan oleh Pritchard (2015.p4) adalah perencanaan manajemen risiko, identifikasi risiko, analisis kualitatif, perhitungan kuantitatif, perencanaan respons risiko dan kontrol risiko. Penelitian ini dilakukan mulai dari perencanaan manajemen risiko, identifikasi, analisis kualitatif dan hanya sampai pada tahapan analisis perhitungan kuantitatif dari penetapan counterparty credit limit bank-bank di Indonesia.

Penelitian ini menggunakan metode rating schemes, expert opinion dan metode Delphi. Metode pendapat ahli (expert opinion) merupakan tahapan awal melakukan penggalian informasi tentang identifikasi dari risiko penetapan counterparty credit limit. Kemudian tahapan pengukuran menggunakan rating schemes. Rating schemes digunakan untuk menentukan tingkat probabilitas dari informasi yang didapatkan dari metode pendapat ahli (expert opinion). Dengan menggunakan metodemetode tersebut, akan diregister berdasarkan kategori risiko (low, moderate, high) dalam penetapan counterparty credit limit bank-bank di Indonesia. Berdasarkan kategori risiko-risiko tersebut, maka dibuat matriks risiko dari penetapan counterparty credit limit bank-bank. Kemudian metode Delphi untuk menentukan risiko yang paling penting dari dimensi kemungkinan (probabilitas) dan dimensi dampak (impact) untuk mendapatkan perencanaan respon risiko dan control terhadap risiko dari bankbank yang ada di Indonesia.

\section{Definisi Kredit}

Menurut Undang - Undang Perbankan Nomor 10 Tahun 1998 kredit adalah penyediaan uang atau tagihan yang dapat dipersamakan dengan itu, berdasarkan persetujuan atau kesepakatan pinjam meminjam melunasi utangnya setelah jangka waktu tertentu dengan pemberian bunga.

\section{Risiko Kredit}

Menurut Peraturan Otoritas Jasa Keuangan Nomor 18 /POJK.03/2016 tentang penerapan manajemen risiko bagi bank umum yang termasuk dalam kelompok risiko kredit adalah risiko konsentrasi kredit, counterparty credit risk, dan settlement risk.

1. Risiko konsentrasi kredit merupakan Risiko yang timbul akibat terkonsentrasinya penyediaan dana kepada 1 (satu) pihak atau sekelompok pihak, industri, sektor, dan/atau area geografis tertentu yang berpotensi menimbulkan kerugian cukup besar yang dapat mengancam kelangsungan usaha Bank.

2. Counterparty Credit Risk merupakan Risiko yang timbul akibat terjadinya kegagalan pihak lawan dalam memenuhi kewajibannya dan timbul dari jenis transaksi yang memiliki karakteristik tertentu, misalnya transaksi yang dipengaruhi oleh pergerakan nilai wajar atau nilai pasar.

3. Settlement risk merupakan Risiko yang timbul akibat kegagalan penyerahan kas dan/atau instrumen keuangan pada tanggal penyelesaian (settlement date) yang telah disepakati dari transaksi penjualan dan/atau pembelian instrumen keuangan. 
Risiko kredit juga terdapat pada aktivitas treasury. Risiko kredit pada aktivitas treasury misalnya bank membeli obligasi korporasi, melakukan investasi dengan membeli surat berharga, melakukan pembiayaan perdagangan (trade finance), baik yang tercatat dalam banking book maupun trading book. Selain itu di treasury juga ada aktivitas penempatan dana kepada bank lain. Pada umumnya, limit penempatan kepada bank lain bersifat clean, artinya tidak mensyaratkan penyerahan agunan dari bank yang menerima penyimpanan dana (IBI dan BARa, 2015, p8).

\section{Tahapan Manajemen Risiko}

Manajemen risiko merupakan sebuah proses perencanaan risiko untuk mengidentifikasi, menilai dan mengembangkan respon risiko untuk kepentingan organisasi (Pritchard, 2015.p1). Penjelasan tiap langkah di dalam manajemen risiko adalah sebagai berikut:

1. Perencanaan Manajemen Risiko. Hal yang dilakukan di dalam perencanaan manajemen risiko adalah pengembangan infrastruktur organisasi untuk mendukung semua proses risiko lainnya.

2. Identifikasi risiko adalah proses mengidentifikasikan risiko organisasi.

3. Analisis kualitatif merupakan pemilahan risiko berdasarkan probabilitas dan dampak umum untuk memudahkan analisis terhadap risiko yang paling kritis.

4. Analisis kuantitatif adalah proses kuantifikasi risiko dan mengasah kuantifikasi tersebut untuk menilai dampak terhadap biaya, jadwal dan kualitas area proyek tertentu serta untuk menilai dampak proyek secara keseluruhan.

5. Perencanaan respons risiko melibatkan evaluasi dan penyempurnaan strategi mitigasi risiko.

6. Pemantauan dan pengendalian risiko mencakup penerapan strategi mitigasi risiko dan evaluasi serta pencatatannya.

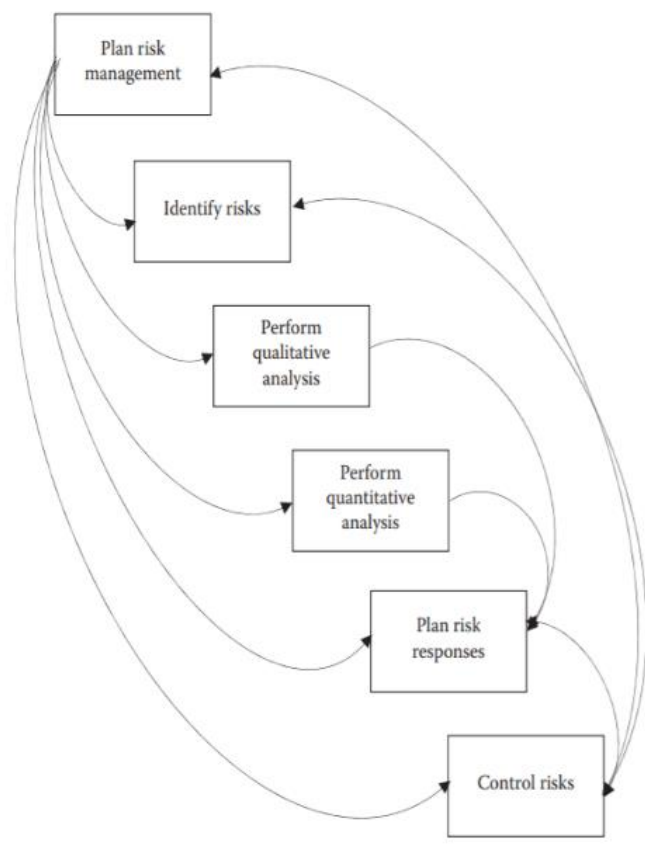

Gambar 1. Risk Management Processes Sumber: Pritchard, Carl L (2015, p.24) 


\section{Metode Expert Opinion}

Tahapan identifikasi risiko dapat dilakukan dengan metode analisis data histori, pengamatan dan survei, pengacuan dan benchmarking. Namun apabila mengalami kesulitan dari ketiga metode tersebut, maka dapat menggunakan teknik pendapat ahli (expert opinion). Pendapat ahli (expert opinion) dapat diperoleh dengan cara wawancara 1 orang. Selain itu, teknik ini juga dapat mengidentifikasi risiko terkait dengan lingkungan serta kerja sama dengan institusi atau organisasi lain. Expert opinion berfokus pada penggalian informasi tentang risiko dan seberapa parah kejadian tersebut. Langkah dalam mengaplikasikan metode expert judgement menurut Pritchard (2015,p.67) adalah sebagai berikut:

1. Mengidentifikasi individu atau ahli yang sesuai. Apabila ada keraguan tentang keahlian ahli, ada baiknya untuk menemukan satu atau dua ahli yang lain.

2. Menyiapkan wawancara dengan menyusun daftar agenda atau topik untuk memastikan bahwa diskusi yang dilakukan memiliki arahan yang jelas.

3. Langkah terakhir dalam pengaplikasian metode expert judgment adalah mengharuskan ahli untuk mempertimbangkan kemungkinan (probabilitas) terjadinya kejadian risiko dan dampak (impact) potensialnya.

Menurut Sugiyono (2015:80) populasi merupakan "wilayah generalisasi yang terdiri atas objek/ subjek yang mempunyai kualitas dan karakteristik tertentu yang ditetapkan oleh peneliti untuk mempelajari dan kemudian ditarik kesimpulannya". Menurut OJK pada bulan Januari 2020 total bank di Indonesia yang beroperasi berjumlah 110 bank. Dengan demikian populasi dari penelitian ini adalah 110 bank yang ada di Indonesia. Sample pada penelitian ini berdasarkan pengumpulan data selama bulan Januari - Juni 2020 mendapatkan responden sebanyak 59 orang ahli (expert) di bidangnya (financial institution) dan berasal dari bank-bank yang berbeda. Respoden ahli (expert) yang berjumlah 59 orang ini merupakan orang yang memahami dan bertanggungjawab menangani dari penetapan counterparty credit limit. Responden ahli (expert) berasal dari Bank Buku IV (7 orang), Bank Buku III (18 orang), Bank Buku II (29 orang), Bank Buku I (3 orang), Bank Asing (2 orang). Jadi total responden berjumlah 59 bank dari total 110 Bank di Indonesia baik konvensional atau Syariah.

\section{Metode Rating Schemes}

Rating schemes merupakan sebuah standarisasi yang digunakan untuk menilai risiko yang terjadi di sebuah instansi. Sebuah risiko memiliki dampak dan probabilitas yang berbeda-beda dan persepsi mengenai risiko antara satu orang dengan yang lain berbeda. Ada yang menyebutkan bahwa risiko tersebut 'low' atau 'high' atau 'moderate'. Teknik ini mengklarifikasi besaran relatif dalam hal dampak dan probabilitas sehingga terdapat definisi dan cara menguji risiko yang paten. Sehingga semua orang di dalam instansi dapat memandang atau menilai risiko dengan cara yang sama (Pritchard, 2015, p.66). 
Menurut Djohanputro (2008, p.240), umumnya probabilitas dan dampak dibagi ke dalam tiga kategori: tinggi, sedang, dan rendah. Dimensi probabilitas menunjukkan semakin tinggi kemungkinan suatu risiko terjadi, semakin perlu mendapat perhatian. Sedangkan dimensi dampak menjelaskan bahwa semakin tinggi dampak suatu risiko, semakin perlu mendapat perhatian khusus.

\section{Metode Delphi Dan Pengukuran Konsensus}

Metode Delphi secara definisi adalah proses dalam kelompok yang melibatkan interaksi antara peneliti dan sekelompok ahli terkait topik tertentu; biasanya melalui bantuan kuesioner. Metode ini digunakan untuk mendapatkan konsensus mengenai proyeksi/tren masa depan menggunakan proses pengumpulan informasi yang sistematis. Metode ini berguna pada saat pendapat dan penilaian dari para ahli dan praktisi dibutuhkan dalam menyelesaikan masalah. Ini akan sangat berguna ketika para ahli tidak bisa dihadirkan pada saat yang sama (Rum dan Ratni, 2018:p1).

Adapun instrumen yang ada telah konvergen atau tercapai konsensus dari para narasumber yang menilai penting untuk dikembangkan adalah menggunakan analisa statistik dengan pendekatan:

1. Standar Deviasi Ukuran pertama penilaian konvergensi atau konsensus adalah ketika jawaban atau penilaian dari seluruh narasumber memiliki standar deviasi $<1,5$. Adapun rumus Standar Deviasi adalah sebagai berikut:

$$
s=\sqrt{\frac{\Sigma\left(x_{i}-\bar{x}\right)^{2}}{n-1}} \text { atau } \sqrt{\frac{\sum x_{i}^{2}-\frac{\left(\Sigma x_{i}\right)^{2}}{n}}{n-1}}
$$

Dimana: $\mathrm{x}=$ jawaban responen A terhadap instrumen $\mathrm{n} \overline{x=}$ rata - rata jawaban responden terhadap instrumen $\mathrm{n}$

2. Interquartile Range (Jangkauan interkuartile) Ukuran kedua penilaian konvergensi atau konsensus adalah ketika jawaban atau penilaian dari seluruh narasumber memiliki Interquartile Range

$\mathrm{IR}=\mathrm{Q} 3-\mathrm{Q} 1$

Dimana Q3 adalah Kuartil atas dan Q1 adalah Kuartil Bawah. Adapun rumus Kuartil atas adalah:

$$
\begin{aligned}
& Q_{1}=\frac{x\left(\frac{n-1}{4}\right)+x\left(\frac{n+3}{4}\right)}{2} \\
& Q_{2}=x\left(\frac{2(n+1)}{4}\right) \\
& Q_{3}=\frac{x\left(\frac{(n n+1}{4}\right)+x\left(\frac{3 n+5}{4}\right)}{2}
\end{aligned}
$$

Evaluasi untuk menyatakan konvergensi atau konsensus terhadap seluruh instrument adalah, ketika standar deviasi $<1,5$ dan interquartile range $<2,5$. Jika salah satu baik standar deviasi maupun 
interquartile range tidak bernilai $<1,5$ dan $<2,5$, maka instrument tersebut dinyatakan tidak konvergen atau tidak disepakati (konsensus) bahwa instrumen tersebut penting dan potensial untuk dikembangkan.

\section{METODE RISET}

Tahapan atau langkah-langkah yang dilakukan di dalam penelitian terkait risk planning, risk identification, risk assessment dari penetapan counterparty credit limit bank-bank di Indonesia. Penjabaran dari langkah-langkah di dalam pendefinisian risk planning, risk identification, risk assessment dari penetapan counterparty limit bank-bank di Indonesia adalah sebagai berikut:

1. Risk planning, tahapan ini digunakan untuk mempersiapkan infrastruktur atau sumber daya yang dapat digunakan untuk tahap mengidentifikasi risiko.

2. Risk Identification, tahapan ini digunakan untuk menggambarkan apa saja yang berpotensi menimbulkan risiko pada saat penetapan counterparty credit limit bank. Tahapan identifikasi risiko dilakukan menganalisa sistem, alur proses dan prosedur penetapan limit dengan metode expert opinion.

Menurut Dalkey dalam Rum dan Ratni (2018: 4), karakteristik umum dalam metode ini bisa dijelaskan sebagai berikut:

a. Anonim, artinya dalam penggunaan kuesioner atau komunikasi lainnya yang berkaitan dengan respon, identifikasi dari anggota panelis dinyatakan secara anonim (tertutup).

b. Ada kontrol feedback, artinya dengan adanya kontrol tersebut memungkinkan interaksi antara anggota panelis untuk mengurangi distorsi. Interaksi tersebut terjadi pada setiap tahapan, dimana hasil tahapan sebelumnya akan diberikan pada tahapan berikutnya dan anggota panelis diminta kembali untuk mengevaluasi penilaian awal mereka dengan membandingkan dengan penilaian kelompok.

c. Respon kelompok secara stastistik, artinya penilaian kelompok dinyatakan sebagai ratarata statistik dari penilaian anggota panelis, dimana penilaian setiap anggota panelis tercermin dalam respon terakhir tersebut.

3. Risk Assessment, tahapan ini mengacu pada dua faktor: kuantitas risiko dan kualitas risiko. Kuantitas risiko terkait dengan berapa banyak nilai, atau eksposur, yang rentan terhadap risiko. Kualitas risiko terkait dengan kemungkinan suatu risiko muncul. Jadi pengukuran terkait dengan kemungkinan (probabilitas) dan dampak (impact). Metode kualitatif dari tahapan manajemen risiko yang digunakan di dalam penelitian ini adalah metode rating schemes. 


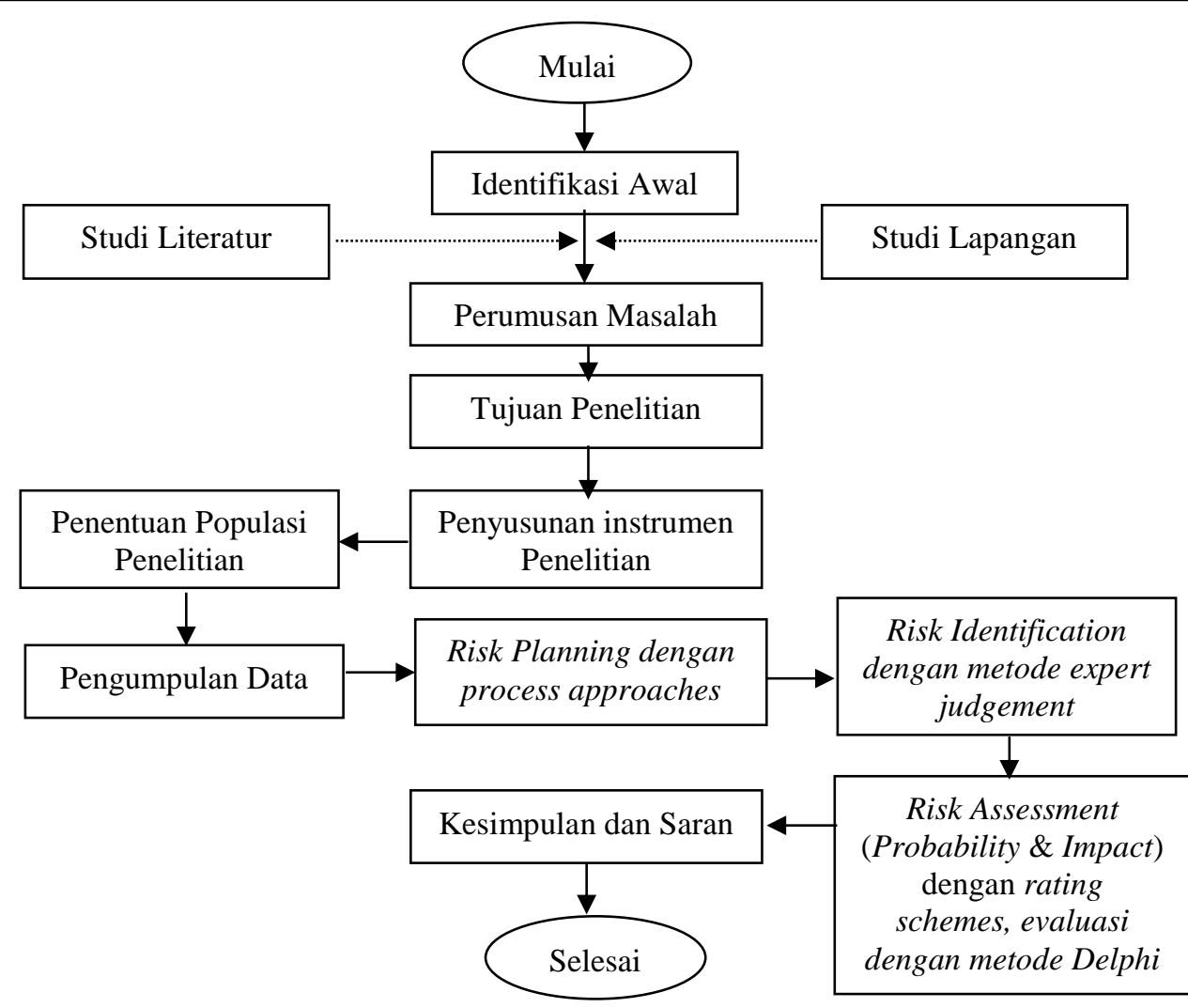

Gambar 2. Metodologi Penelitian

Sumber: diolah sendiri (2020)

\section{HASIL PENELITIAN DAN PEMBAHASAN}

\section{Hasil Perencanaan Risiko}

Perencanaan risiko merupakan hal-hal yang dibutuhkan agar proyek dapat terorganisir dan terarah, contohnya deskripsi, ringkasan proyek, faktor lingkungan (risk environment), pendekatan risiko (approach to risk management), pendekatan proses (process approach), risk governance, bibliography (supporting documentation) dan lain-lain. Perencanaan risiko yang digunakan dalam penelitian ini melalui pendekatan proses (process approach).

\section{Hasil Identifikasi Risiko}

Proses identifikasi dilakukan dengan menganalisis sumber risiko dari seluruh aktivitas bank, minimal dilakukan terhadap risiko produk dan aktivitas bank, serta memastikan bahwa risiko dari produk dan aktivitas baru telah melalui proses manajemen risiko yang layak sebelum diperkenalkan atau dijalankan (IBI dan BARa, 2015:32). Menurut Project Management Institute, Inc (PM) dalam Pritchard (2015: p.34) metode yang digunakan untuk identifikasi risiko antara lain review dokumentasi, teknik pengumpulan informasi (termasuk analisis SWOT), daftar checklist, analisis asumsi dan teknik diagram (flow chart). Pendekatan yang dilakukan dalam penelitian ini adalah teknik diagram (flow chart) proses penetapan counterparty credit limit. 


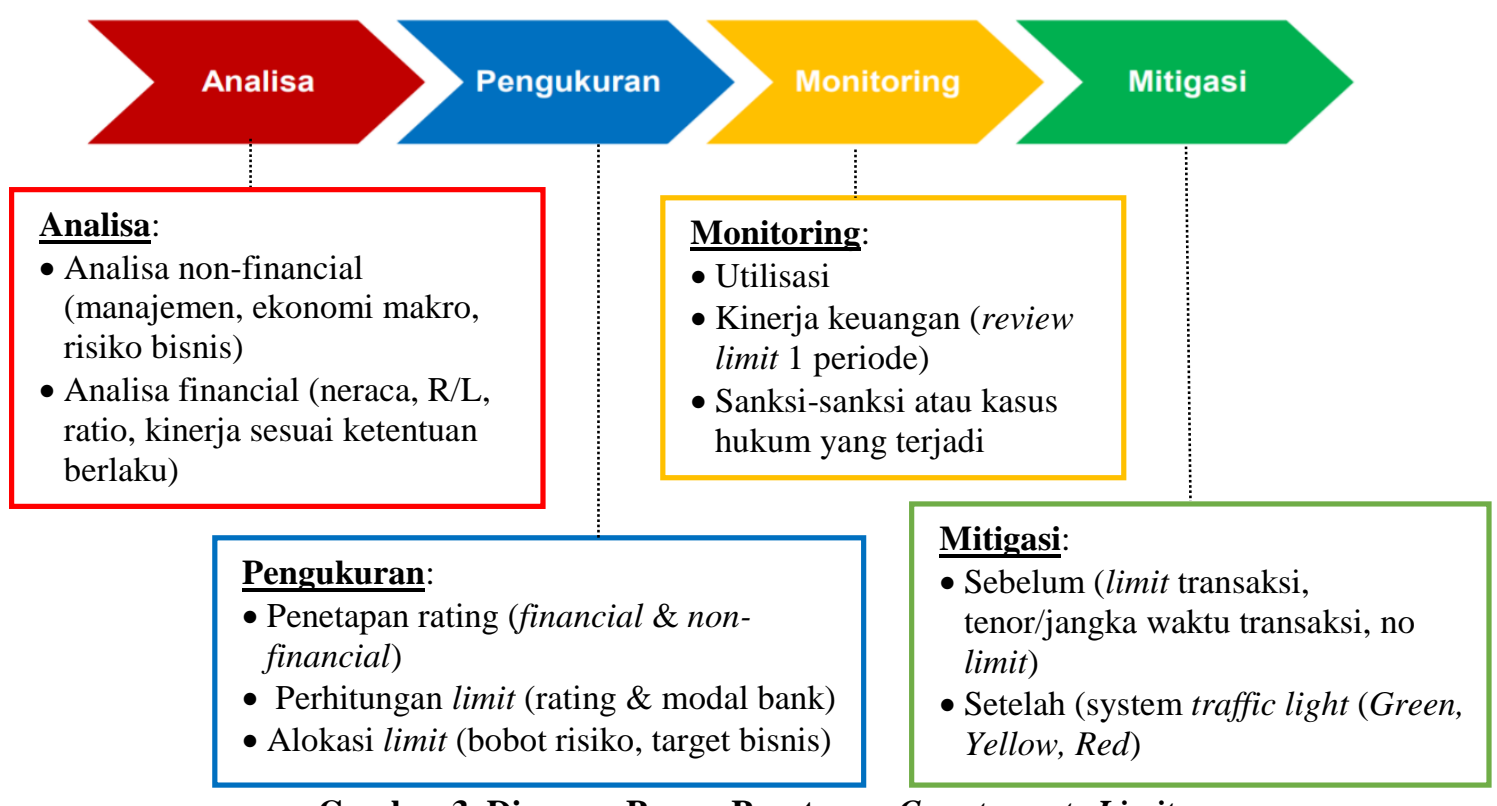

Gambar 3. Diagram Proses Penetapan Counterparty Limit

Sumber: data diolah sendiri (2020)

Proses penetapan counterparty limit meliputi proses analisa (financial dan non-financial), pengukuran (rating, limit transaksi dan alokasi limit), monitoring (utilisasi penggunaan limit, kinerja counterparty dan sanksi-sanksi hukum yang dihadapi) dan mitigasi (sebelum dan sesudah penetapan limit). Berdasarkan diagram proses (flow chart) di atas, maka sebagai berikut hasil register risiko Penetapan Counterparty credit limit Bank-Bank di Indonesia sebagai berikut dibawah ini:

Tabel 1. Hasil Register Risiko Counterparty credit limit Bank-Bank di Indonesia

\begin{tabular}{cl}
\hline No & \multicolumn{1}{c}{ Risiko - Risiko Counterparty credit limit Bank } \\
\hline 1 & Tidak melakukan kunjungan kepada counterparty \\
2 & $\begin{array}{l}\text { Tidak menanggapi permintaan counterparty untuk pembukaan hubungan sebagai nasabah atau bank } \\
\text { koresponden }\end{array}$ \\
3 & Salah dalam menilai potensi bisnis counterparty \\
4 & Salah dalam menganalisa manajemen counterparty (pemilik dari bank koresponden (UBO), pengurus \\
& dan struktur organisasi, kebutuhan KYC/AML) \\
5 & Salah dalam menganalisa ekonomi makro dan industri perbankan yang berdampak pada counterparty \\
& (ekonomi global, perubahan peraturan atau regulasi otoritas moneter, perubahan peraturan pemerintah) \\
6 & Salah dalam menganalisa risiko bisnis counterparty (komposisi portfolio, segmen nasabah, strategi bank \\
& koresponden). \\
7 & Salah dalam menganalisa kinerja keuangan counterparty (analisa neraca, laporan R/L, financial ratio) \\
8 & Salah dalam penetapan rating counterparty \\
9 & Salah dalam perhitungan limit counterparty (formulasi limit dan modal bank). \\
10 & Salah dalam mengalokasi limit counterparty (bobot risiko transaksi \& target bisnis berdasarkan \\
& proyeksi). \\
11 & Salah dalam menganalisa proyeksi kemampuan counterparty dalam jangka waktu lebih dari 1 tahun \\
12 & Tidak memonitor utilisasi limit counterparty \\
13 & Tidak memonitor kinerja keuangan counterparty (review limit dalam 1 periode saja). \\
14 & Tidak memonitor dan memperhatikan sanksi-sanksi atau kasus hukum yang terjadi pada counterparty \\
15 & Tidak membatasi dan memonitoring seluruh transaksi yang berjalan yang menggunakan limit \\
& counterparty \\
16 & Tidak membatasi tenor/jangka waktu transaksi \\
17 & Memberikan limit walaupun proses penetapan counterparty limit belum selesai \\
18 & Tidak melakukan due diligence secara rutin \\
\hline &
\end{tabular}

Sumber: data diolah sendiri (2020) 


\section{Hasil Analisis Kualitatif Pendapat Ahli (Expert Opinion)}

Pada tahapan selanjutnya setelah mengidentifikasi adalah mengukur risiko-risiko secara kualitatif. Dalam hal ini menilai dengan menggabungkan kemungkinan terjadinya sebuah risiko (probability) serta dampak (impact) dari risiko tersebut. Penilaian kualitatif para ahli (expert) melalui kuesioner dan adanya kontrol feedback sehingga memungkinkan interaksi dan evaluasi terhadap penilaian awal mereka.

Tabel 2. Hasil Pengukuran Kualitatif Expert Opinion

\begin{tabular}{|c|c|c|c|c|c|c|}
\hline \multirow{2}{*}{$\begin{array}{c}\text { Risiko } \\
\text { No }\end{array}$} & \multicolumn{3}{|c|}{ Kemungkinan (Probability) } & \multicolumn{3}{|c|}{ Dampak (Impact) } \\
\hline & Low & Medium & High & Low & Medium & High \\
\hline 1 & $\sqrt{ }$ & & & & $\sqrt{ }$ & \\
\hline 2 & & $\sqrt{ }$ & & & $\sqrt{ }$ & \\
\hline 3 & & & $\sqrt{ }$ & & & $\sqrt{ }$ \\
\hline 4 & & $\sqrt{ }$ & & & & $\sqrt{ }$ \\
\hline 5 & & $\sqrt{ }$ & & & & $\sqrt{ }$ \\
\hline 6 & & $\sqrt{ }$ & & & $\sqrt{ }$ & \\
\hline 7 & & & $\sqrt{ }$ & & & $\sqrt{ }$ \\
\hline 8 & & $\sqrt{ }$ & & & & $\sqrt{ }$ \\
\hline 9 & & & $\sqrt{ }$ & & & $\sqrt{ }$ \\
\hline 10 & & $\sqrt{ }$ & & & & $\sqrt{ }$ \\
\hline 11 & & $\sqrt{ }$ & & & & $\sqrt{ }$ \\
\hline 12 & & $\sqrt{ }$ & & & $\sqrt{ }$ & \\
\hline 13 & & $\sqrt{ }$ & & & & $\sqrt{ }$ \\
\hline 14 & & & $\sqrt{ }$ & & & $\sqrt{ }$ \\
\hline 15 & & $\sqrt{ }$ & & & & $\sqrt{ }$ \\
\hline 16 & & & $\sqrt{ }$ & & & $\sqrt{ }$ \\
\hline 17 & & & $\sqrt{ }$ & & & $\sqrt{ }$ \\
\hline 18 & & $\sqrt{ }$ & & & & $\sqrt{ }$ \\
\hline
\end{tabular}

\section{Hasil Analisis Kuantitatif Risiko}

Perusahaan akan berusaha untuk memaksimumkan nilai perusahaan dengan segala keterbatasan sumber daya yang ada. Karena keterbatasan sumber daya tersebut, maka pemetaan risiko perusahaan merupakan upaya perusahaan untuk menetapkan prioritas dalam penanganan risiko. Matriks risiko terkait dengan dua dimensi, yaitu dimensi probabilitas (kemungkinan) dan dimensi impact (dampak). Matriks risiko juga dikenal sebagai matriks probabilitas dan dampak. Berikut ini matriks pemetaan risiko dari penetapan Counterparty credit limit Bank-Bank di Indonesia.

Tabel 3. Matriks Risiko

\begin{tabular}{cccc}
\hline \multirow{2}{*}{ Kemungkinan (Probability) } & \multicolumn{2}{c}{ Dampak (Impact) } \\
\cline { 2 - 3 } & Low & Medium & High \\
\hline Low & R1 & \\
Medium & & R2, R6, R12, & R4, R5, R8, R10, R11, R13, R15, R18 \\
High & & R3, R7, R9, R14, R16, R17 \\
\hline
\end{tabular}

Angka 1 - 18 menunjukkan nomor urut risiko dari Tabel 1. Pada Tabel 3 menunjukkan Probability - Impact pada kuadran Low - Medium terdapat 1 risiko. Kemudian pada kuadran Medium - Medium terdapat 3 risiko. Pada kuadran Medium-High terdapat 8 risiko, sedangkah kuadran HighHigh terdapat 6 risiko. 


\section{Hasil Metode Delphi}

Berdasarkan desain metode Delphi sebagaimana dibahas sebelumnya, dilakukan penarikan opini dari 59 narasumber yang merupakan ahli (expert) dan juga pemangku kepentingan terkait penetapan counterparty credit limit. Untuk menentukan manakah instrumen yang paling penting dari dimensi probabilitas (kemungkinan) dan dimensi impact (dampak).

Tabel 4. Hasil Metode Delphi Dimensi Probabilitas (Probability)

\begin{tabular}{|c|c|c|c|c|c|c|c|c|c|}
\hline \multirow{2}{*}{ No } & \multirow{2}{*}{ Rata } & \multirow{2}{*}{ Std. Dev } & \multirow{2}{*}{ Mod } & \multicolumn{3}{|c|}{ Quartil } & \multirow[t]{2}{*}{ IR } & \multicolumn{2}{|c|}{ Evaluasi } \\
\hline & & & & Q1 & Q2 & Q3 & & Std. Dev & IR \\
\hline 1 & 1,61 & 0,70 & 1 & 1 & 1 & 2 & 1 & Kon & Kon \\
\hline 2 & 1,88 & 0,65 & 2 & 1 & 2 & 2 & 1 & Kon & Kon \\
\hline 3 & 2,15 & 0,81 & 3 & 1 & 2 & 3 & 2 & Kon & Kon \\
\hline 4 & 2,14 & 0,73 & 2 & 2 & 2 & 3 & 1 & Kon & Kon \\
\hline 5 & 2,20 & 0,64 & 2 & 2 & 2 & 3 & 1 & Kon & Kon \\
\hline 6 & 2,05 & 0,68 & 2 & 2 & 2 & 3 & 1 & Kon & Kon \\
\hline 7 & 2,29 & 0,83 & 3 & 2 & 3 & 3 & 1 & Kon & Kon \\
\hline 8 & 2,03 & 0,79 & 2 & 1 & 2 & 3 & 2 & Kon & Kon \\
\hline 9 & 2,15 & 0,83 & 3 & 1 & 2 & 3 & 2 & Kon & Kon \\
\hline 10 & 2,14 & 0,71 & 2 & 2 & 2 & 3 & 1 & Kon & Kon \\
\hline 11 & 2,19 & 0,73 & 2 & 2 & 2 & 3 & 1 & Kon & Kon \\
\hline 12 & 2,00 & 0,81 & 2 & 1 & 2 & 3 & 2 & Kon & Kon \\
\hline 13 & 2,02 & 0,80 & 2 & 1 & 2 & 3 & 2 & Kon & Kon \\
\hline 14 & 2,29 & 0,72 & 3 & 2 & 2 & 3 & 1 & Kon & Kon \\
\hline 15 & 2,17 & 0,75 & 2 & 2 & 2 & 3 & 1 & Kon & Kon \\
\hline 16 & 2,15 & 0,78 & 3 & 2 & 2 & 3 & 1 & Kon & Kon \\
\hline 17 & 2,14 & 0,88 & 3 & 1 & 2 & 3 & 2 & Kon & Kon \\
\hline 18 & 2,14 & 0,71 & 2 & 2 & 2 & 3 & 1 & Kon & Kon \\
\hline
\end{tabular}

Berdasarkan peringkat pada dimensi kemungkinan (probability), terdapat risiko yang paling penting yaitu salah dalam menganalisa kinerja keuangan counterparty (analisa neraca, laporan R/L, financial ratio) dan tidak memonitor dan memperhatikan sanksi-sanksi atau kasus hukum yang terjadi pada counterparty dengan nilai 2,29 dan para ahli (expert) telah tercapai konvergensi atau konsensus. Pada dimensi dampak (impact) berdasarkan peringkat, maka risiko yang paling penting yaitu salah dalam menganalisa kinerja keuangan counterparty (analisa neraca, laporan R/L, financial ratio) dengan nilai 2,78 dan para ahli (expert) telah tercapai konvergensi atau konsensus. 
Tabel 4. Hasil Metode Delphi Dimensi Dampak (Impact)

\begin{tabular}{|c|c|c|c|c|c|c|c|c|c|}
\hline \multirow{2}{*}{ No } & \multirow{2}{*}{ Rata } & \multirow{2}{*}{ Std. Dev } & \multirow{2}{*}{ Mod } & \multicolumn{3}{|c|}{ Quartil } & \multirow{2}{*}{ IR } & \multicolumn{2}{|c|}{ Evaluasi } \\
\hline & & & & Q1 & Q2 & Q3 & & Std. Dev & IR \\
\hline 1 & 1,81 & 0,68 & 2 & 1 & 2 & 2 & 1 & Kon & Kon \\
\hline 2 & 2,19 & 0,73 & 2 & 2 & 2 & 3 & 1 & Kon & Kon \\
\hline 3 & 2,58 & 0,62 & 3 & 2 & 3 & 3 & 1 & Kon & Kon \\
\hline 4 & 2,61 & 0,56 & 3 & 2 & 3 & 3 & 1 & Kon & Kon \\
\hline 5 & 2,56 & 0,57 & 3 & 2 & 3 & 3 & 1 & Kon & Kon \\
\hline 6 & 2,32 & 0,68 & 2 & 2 & 2 & 3 & 1 & Kon & Kon \\
\hline 7 & 2,78 & 0,49 & 3 & 3 & 3 & 3 & 0 & Kon & Kon \\
\hline 8 & 2,42 & 0,75 & 3 & 2 & 3 & 3 & 1 & Kon & Kon \\
\hline 9 & 2,59 & 0,62 & 3 & 2 & 3 & 3 & 1 & Kon & Kon \\
\hline 10 & 2,39 & 0,67 & 3 & 2 & 2 & 3 & 1 & Kon & Kon \\
\hline 11 & 2,51 & 0,63 & 3 & 2 & 3 & 3 & 1 & Kon & Kon \\
\hline 12 & 2,29 & 0,70 & 2 & 2 & 2 & 3 & 1 & Kon & Kon \\
\hline 13 & 2,46 & 0,65 & 3 & 2 & 3 & 3 & 1 & Kon & Kon \\
\hline 14 & 2,69 & 0,53 & 3 & 2 & 3 & 3 & 1 & Kon & Kon \\
\hline 15 & 2,68 & 0,51 & 3 & 2 & 3 & 3 & 1 & Kon & Kon \\
\hline 16 & 2,58 & 0,59 & 3 & 2 & 3 & 3 & 1 & Kon & Kon \\
\hline 17 & 2,63 & 0,67 & 3 & 2 & 3 & 3 & 1 & Kon & Kon \\
\hline 18 & 2,46 & 0,68 & 3 & 2 & 3 & 3 & 1 & Kon & Kon \\
\hline
\end{tabular}

\section{KESIMPULAN DAN SARAN}

\section{Kesimpulan}

1. Hasil identifikasi risiko menggunakan pendapat ahli (expert opinion) terdapat 18 risiko yang dihadapi oleh bank-bank di Indonesia dalam penetapan counterparty credit limit.

2. Pengukuran risiko secara kualitatif dengan rating schemes menunjukkan bahwa risiko dapat digolongkan pada rendah (low), sedang (medium) dan tinggi (high). Pada tahap pemetaan risiko pada kuadran Low - Medium terdapat 1 risiko. Kemudian pada kuadran Medium - Medium terdapat 3 risiko. Pada kuadran Medium-High terdapat 8 risiko, sedangkan kuadran High - High terdapat 6 risiko.

3. Hasil metode delphi dari dimensi probabilitas menunjukkan risiko yang paling penting yaitu salah dalam menganalisa kinerja keuangan counterparty (analisa neraca, laporan R/L, financial ratio) dan tidak memonitor dan memperhatikan sanksi-sanksi atau kasus hukum yang terjadi pada counterparty dengan nilai 2,29 dan para ahli (expert) telah tercapai konvergensi atau konsensus. Sedangkan dari dimensi dampak risiko yang paling penting yaitu salah dalam 
menganalisa kinerja keuangan counterparty (analisa neraca, laporan $\mathrm{R} / \mathrm{L}$, financial ratio) dengan nilai 2,78 dan para ahli (expert) telah tercapai konvergensi atau konsensus.

\section{Saran}

1. Perlunya bank-bank di Indonesia untuk memberikan pelatihan atau training kepada para petugas/pejabat financial institution mengenai bagaimana menganalisis kinerja keuangan counterparty dengan baik dan benar (misalnya analisa neraca, arus kas, laporan R/L, financial ratio).

2. Petugas/pejabat Financial institution bank-bank di Indonesia perlu mengupdate informasi perbankan terkini melalui media televisi, cetak/online, radio bahkan timeline media sosial. Selain itu hendaknya melakukan due diligence secara rutin dan memonitoring seluruh transaksi yang berjalan

3. Penelitian ini hanya sampai pada tahap perencanaan risiko, identifikasi, analisis kualitatif dan pengukuran kuantitatif risiko. Oleh sebab itu diperlukan penelitian lanjutan meliputi perencanaan respon risiko dan pemantauan dan pengendalian risiko (meliputi mitigasi risiko) agar setiap bank-bank di Indonesia dapat menerapkan manajemen risiko secara terintegrasi dalam hal penetapan counterparty credit limit.

\section{Keterbatasan Penelitian}

Penelitian ini juga terkendala pada adanya ahli (expert) dari bank-bank yang menjadi populasi penelitian tidak bersedia menjadi responden dari penelitian ini. 


\section{DAFTAR PUSTAKA}

Departemen Penelitian dan Pengaturan Perbankan Otoritas Jasa Keuangan. (2015). Penyempurnaan Kerangka Counterparty Credit Risk Basel II Dan III. Jakarta.

Departemen Penelitian dan Pengaturan Perbankan Otoritas Jasa Keuangan. (2016). Pendekatan Standar Untuk Counterparty Credit Risk (Sa-Ccr). Jakarta.

Djohanputro, Bramantyo. (2008). Manajemen Risiko Korporat. Penerbit PPM. Jakarta.

Herfini, Emmawati., dan Jogiyanto, Hartono. (2013). Analisis Penilaian Counterparty Credit Risk Untuk Kebijakan Penetapan Credit Line Kepada Bank-Bank Koresponden Di Negara Eropa oleh PT. Bank ABC (Persero), Tbk Pada Masa Krisis Ekonomi Eropa (Tesis). Yogyakarta (ID): Universitas Gadjah Mada.

Ikatan Bankir Indonesia (IBI) dan Banker Association for Risk Management (BARa). (2015). Manajemen Risiko 1. Modul Sertifikasi Manajemen Risiko Tingkat 1. Jakarta.

Kasmir. (2016). Bank dan Lembaga Keuangan lainnya. Ed. Revisi Cet.17. Rajawali pers. Jakarta

Kurniawati., Theresia LI., Saputra, Mochamad Chandra., dan Rachmadi, Aditya. (2018). Identifikasi dan Analisis Kualitatif Risiko Sistem E-Budgeting dan E-Procurement Studi Kasus: Administrasi Pembangunan Pemerintah Kota Surabaya. Jurnal Pengembangan Teknologi Informasi dan Ilmu Komputer, vol. 2, no. 11, p. 4940-4948, juli 2018. ISSN 2548-964X. Universitas Brawijaya. Malang.

Pritchard, Carl L. (2015). Risk Management Concepts and Guidance Fifth Edition. United States: PMI Book Service Center.

Rum, I.A dan Ratni H. (2018). Modul Metode Delphi. Universitas Padjajaran. Direktorat Jasa Keuangan dan BUMN, Bappenas.

Subagyo, Ahmad, Rusli Simanjuntak dan Alexander Irianto Bukit. (2020). Dasar-Dasar Manajemen Risiko. Edisi Pertama. Mitra Wacana Media. Jakarta.

Sugiyono. (2015). Metode Penelitian Kombinasi (Mix Methods). Bandung: Alfabeta.

Undang-Undang Nomor 10 Tahun 1998

Wiryani., Helen., Achsani, Noer Azam., dan Baga, Lukman M. (2013). Pemetaan Risiko di Industri Penyamakan Kulit dengan Pendekatan Enterprise Risk Management (ERM). Jurnal Manajemen \& Agribisnis, Vol. 10 No. 1 Maret 2013: Institut Pertanian Bogor. Bogor 